\title{
RESPONSE OF SOIL NEMATODES UNDER DIFFERENT PEST MANAGEMENT PRACTICES: A FIELD EXPERIMENTAL APPROACH IN TOMATO (Lycopersicon esculentum L.) GROWING AGRO-ECOSYSTEM
}

\section{Dipak Gupta and Daya Ram Bhusal}

Journal of Institute of Science and Technology

Volume 22, Issue 2, January 2018

ISSN: 2469-9062 (print), 2467-9240 (e)

Editors:

Prof. Dr. Kumar Sapkota

Prof. Dr. Armila Rajbhandari

Assoc. Prof. Dr. Gopi Chandra Kaphle

Mrs. Reshma Tuladhar

JIST, 22 (2): 45-55 (2018)

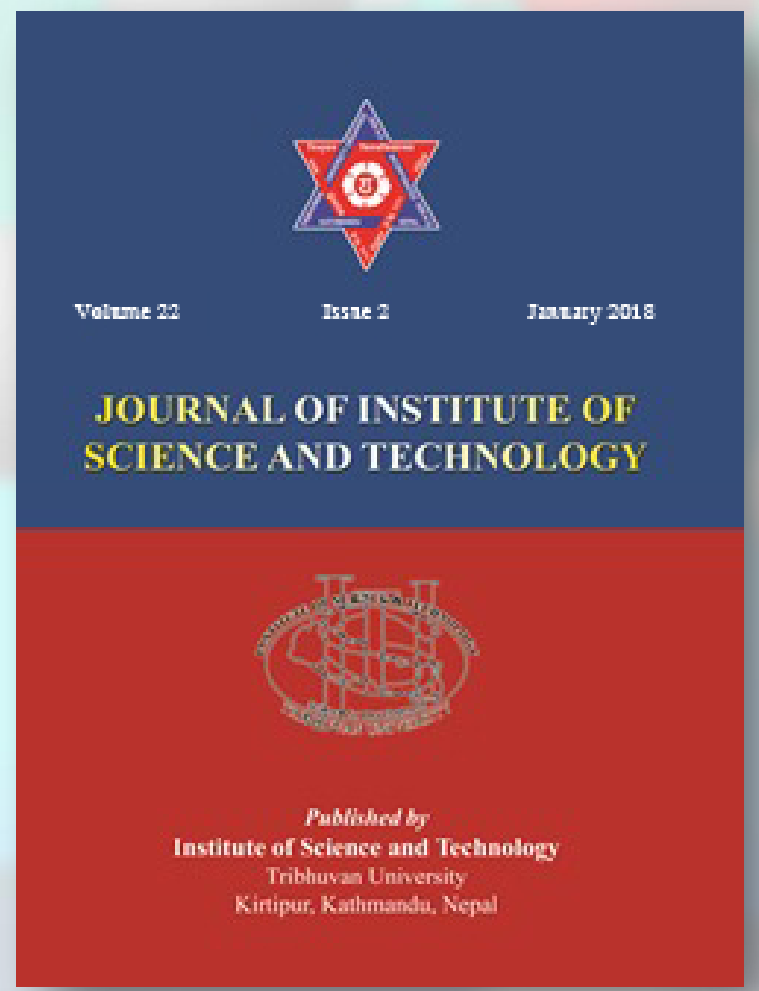

Published by:

Institute of Science and Technology

Tribhuvan University

Kirtipur, Kathmandu, Nepal 


\title{
RESPONSE OF SOIL NEMATODES UNDER DIFFERENT PEST MANAGEMENT PRACTICES: A FIELD EXPERIMENTAL APPROACH IN TOMATO (Lycopersicon esculentum L.) GROWING AGRO-ECOSYSTEM
}

\author{
Dipak Gupta ${ }^{1}$ and Daya Ram Bhusal ${ }^{2, *}$ \\ ${ }^{I}$ Department of Zoology, Amrit Science Campus, Tribhuvan University, Kathmandu, Nepal \\ ${ }^{2}$ Central Departments of Zoology, Tribhuvan University, Kirtipur, Kathmandu, Nepal \\ *Corresponding E-mail: drbhusal@cdztu.edu.np
}

Received: 14 August, 2017; Revised: 10 November, 2017; Accepted: 15 November, 2017

\begin{abstract}
The need of eco-friendly pest management practice is important to maintain soil biodiversity and sustainable agriculture. Therefore rigorous investigation is needed for the environmentally friendly pest management techniques worldwide including Nepalese Tomato growing farms. We conducted field experiment to monitor the diversity and community structure of soil nematodes under different pest management practices in Tomato (Lycopersicon esculentum) growing farm. The study was conducted during summer and winter season in 2015 in Tokha area of Northern part of Kathmandu valley. The field was designed as Urine mixture plot (MP), Pesticides plot (PP), Botanicals plots (BP) and Control plot (CP). Our result indicated the variation of abundance and diversity of nemato-fauna with treatment plots and seasons. The generic diversity and community composition of nematodes in Urine mixture treating plots (MP) was increased significantly whereas decreased in pesticide applying plot (PP). The F/B ratio was significantly affected with treatment system rather than seasonality and found to be increased in pesticides applying plots. The abundance samples of nematodes genera were well separated in our discriminate ordination. We highlight the need of further exploration on the diversity and community dynamics of soil nematodes under different pest management practices in Tomato growing Nepalese agro-farms for sustainable soil ecosystem service.
\end{abstract}

Keywords: Biodiversity, Sustainable agriculture, Pest management, Soil nematodes, Treatment plots.

\section{INTRODUCTION}

Soil biota are important for maintaining soil functionality and regulating processes that support ecosystem services, like nutrient and water retention, carbon storage and pest resistance (Wall et al., 2012; Mulder et al., 2011). Soil Nematodes are a major component of agroecosystem, playing a decisive role in ecosystem services such as nutrient capture, cycling (van der Heijden et al., 2008), control of soil organic matter (SOM), physical structure (Wolters, 2000; Jouquet et al., 2006), and vegetation dynamics (Mitschunas et al., 2006; Forey et al., 2011) with collective effects on crop production (Eisenhauer et al., 2010). They are involved in fundamental ecological process like decomposition (de Goede and Bongers, 1994) and their functional composition is indicative of the major channels of matter and energy transfer across the decomposition pathways. Thus, nematode community structure is a sensitive indicator of the soil status and environmental disturbances (Bongers and Bongers, 1998) these are preferred bioindicators of soil health condition (Bongers and Ferris, 1999; Zhao and Neher, 2005). Nematodes faunal analysis comparing organic and conventional farming systems have been done for commercial fields with different crop management histories (Neher and Olson, 1999). Their indices have been broadly used to assess and monitor soil conditions extending from local fine scales to large landscape properties (Tsiafouli, 2017). Recent work indicated nematodes metabolic foot print can be predicted based on changing bioclimatic parameters (Bhusal et al., 2015). The composition of soil nematode communities is influenced by environmental variables such as vegetation, soil type, season, soil 
moisture level and soil organic matter content (Goralczyk, 1998). The loss of nematofauna causes a serious decline in ecosystem services, consequently bringing about socio-economic losses and food security. The loss of species from food webs due to agricultural intensification (Tsiafouli et al., 2015), random use of pesticides and other management strategies are the possible causes of soil biodiversity loss that demands more rigorous investigation in sustainable soil conservation in agricultural lands. Application of animal and plant byproducts is the foundation of alternative ecofriendly pest management systems that aim to reduce synthetic inputs (Abawi and Widmer, 2000; McSorley and Frederick, 1999), although field experiment in this issue is extremely rare.

Nepalese farmers are constantly under pressure to reduce the use of harmful chemical pesticides and demanding of effective and sustainable alternative eco-friendly pest management method to maintain the sustainability in soil ecosystem function in agro-farms. In this study, we performed field experiments to monitor the response of soil nematodes in differently managed insect pest strategies in Tomato (Lycopersicon esculentum) growing field. We analyzed the diversity and response of functional groups of nematodes with treated plots in different seasons.

\section{MATERIALS AND METHOD}

\section{Study Area:}

The field site is the Tokha Municipality $\left(27^{0} 46^{\prime} 12.69^{\prime \prime} \mathrm{N}\right.$ to $\left.85^{\circ} 19^{\prime} 44.86^{\prime \prime} \mathrm{E}\right)$ of Northern side Kathmandu valley. The proposed study site is an agricultural land where Tomato (Lycopersicon esculentum - Solanaceae Mill) is traditionally and commercially cultivated as one of the main vegetable in Nepal.

\section{Experimental design:}

The field experiment was set up within the plastic house of Tomato (Lycopersicon esculentum Mill) cultivated farm to manage the insect pest to find variation of nematofauna with management practices. In this experiment four types of replicating plots (size $5 \times 5$ sq.m) were established i.e. Cattle urine applied plot (MP), Pesticides applied plot (PP) botanical pesticides applied plots (BP) and control plot (CP). In each plot, 9 replicating soil samples were randomly collected from each plot. Thus, the sampling design of this study represents: 2 seasons $\times 4$ plots $\times 9$ samples were collected for extraction of soil nematodes. The experimental plots were well separated (with plastic bar and tin covered) so as to prevent the adulteration among the experimental plots. In urine mixture plot (MP) mixture solution of cattle urine (1 lit./30 days, where 50\% cattle urine and 50\% water) is applied, in the pesticide plot(BP) extraction of Zanthoxylum armatum (Tewary, 2005) powder was applied (100 gm/ lit water /plot) but in the pesticides plot (PP) plot (mixture of chlorprrifos 50\% and cypermethrin 5\% EC-2ml/lit) chemical pesticide were applied, whereas no any treatment applied in control plot.

\section{Extraction and identification of nematodes:}

Soil samples were randomly collected from different plots (soil cores-diameter $3.5 \mathrm{~cm}$ and depth $15 \mathrm{~cm}$ ) in each of the plots. Nematodes were extracted by the modified Cobb's sieving and decanting method from the soil samples as proposed by S'jacob and Vanbezooijen (1984). A subsample of $100 \mathrm{gm}$ soil (wet weight) was used for extraction. Nematodes were collected after 72 hrs. Total numbers of nematodes were immediately counted using a stereo microscope at 40x magnification. For further analysis, nematodes were heat killed, and fixed with triethanolamine formaldehyde (TAF) 4\% Solution (Shepherd, 1970). Later, from each sample at least 50 nematodes were randomly selected from each sample and observed in different magnifications under compound microscope (Microscope-NikonCi-L, Camera- Nikon-DS-Fi-L2) for identification to genus level using the identification keys of Bongers (1994). They were subsequently allocated to a trophic groups (Bacterivores, Fungivores, Plant parasitic, Omnivores, Predatory,) according toYeates et al. (1993) and to life history strategies (c-p values) according to Bongers (1990). Functional guilds were assigned according to Ferris et al. (2001) by combining the trophic groups to the $c$-value. The colonizer-persister (c-p) values of nematode taxa have been scaled (1-5 scale) based on r-k life-history characteristics that are useful in interpreting the trophic status of the soil food web in different habitats (Bongers, 1990). Functional guilds are defined as a matrix of nematode feeding habits with the biological, ecological and life history characteristics embodied in the c-p classification. Total organic carbon (C) was estimated by Walkley and Black method (Walkely and Black, 1934). The total content of nitrogen in soil was determined by Kjeldahl method (Jones, 1991). The ratio of carbon to nitrogen ratio was calculated. 


\section{DATA ANALYSIS}

The diversity indices of nematode genera and community composition (function guilds and trophic groups) were calculated. ANOVA was performed to find the variation of nemato-fauna with treatment to plots and seasons. Indicator value of each genera and discriminate ordination was carried using suitable package and function in $\mathrm{R}$ ( $\mathrm{R}$ version 3.3.1).

\section{RESULTS}

Listing of nemato-fauna from treatment plots

Altogether 23 genera and 17 families were identified in our experimental plots within two seasons and assigned their respective $\mathrm{cp}$ value. Functional guilds were assigned according to Ferris et al. (2001) by combining the trophic groups to the c-value as shown in table 1 .

Table 1: Listing of genera, respective functional guilds and families from experimental plots in two seasons.

\begin{tabular}{|l|l|l|}
\hline $\begin{array}{c}\text { Trophic group with cp value } \\
\text { (Functional guilds) }\end{array}$ & Genera & \\
\hline ba3 & Achromadora & Cyatholaimidae \\
\hline ba2 & Acrobeles & Cephalobidae \\
\hline ba2 & Acrobeloides & Cephalobidae \\
\hline fu2 & Aphelenchoides & Aphelenchoididae \\
\hline fu2 & Aphelenchus & Aphelenchidae \\
\hline ba2 & Cephalobus & Cephalobidae \\
\hline pf3 & Criconemella & Criconematidae \\
\hline ba1 & Diploscapter & Diploscapteridae \\
\hline fu2 & Ditylenchus & Anguinidae \\
\hline om4 & Dorylaimus & Mydonomidae \\
\hline ba2 & Eucephalobus & Cephalobidae \\
\hline pf3 & Helicotylenchus & Hoplolaimidae \\
\hline ba2 & Heterocephalobus & Cephalobidae \\
\hline pre5 & Longidorous & Longidoridae \\
\hline pf2 & Malenchus & Tylenchidae \\
\hline ba1 & Mesorhabiditis & Rhabditidae \\
\hline om4 & Mononchus & Mononchidae \\
\hline ba1 & Panagrolaimus & Panagrolaimidae \\
\hline pf2 & Pratylenchus & Pratylenchidae \\
\hline ba3 & prismatolaimus & Prismatolaimidae \\
\hline ba1 & Rhabditis & Rhabditidae \\
\hline pf4 & Trichodorous & Trichodoridae \\
\hline ba2 & Zeldia & Cephalobidae \\
\hline & & \\
\hline
\end{tabular}

\section{Quantification of nematode diversity:}

To quantify the diversity status soil nematodes genera in experimental plots, the Renyi diversity index for four treatment plots were performed as depicted in figure 1 . The urine mixture treated plot (MP) was characterized by a high degree of generic diversity. Higher Shannon and high value of inverse Simpson (Invsim) and evenness was obtained but low value of these diversity indices have been resulted in the chemical pesticide applied plot (PP). 


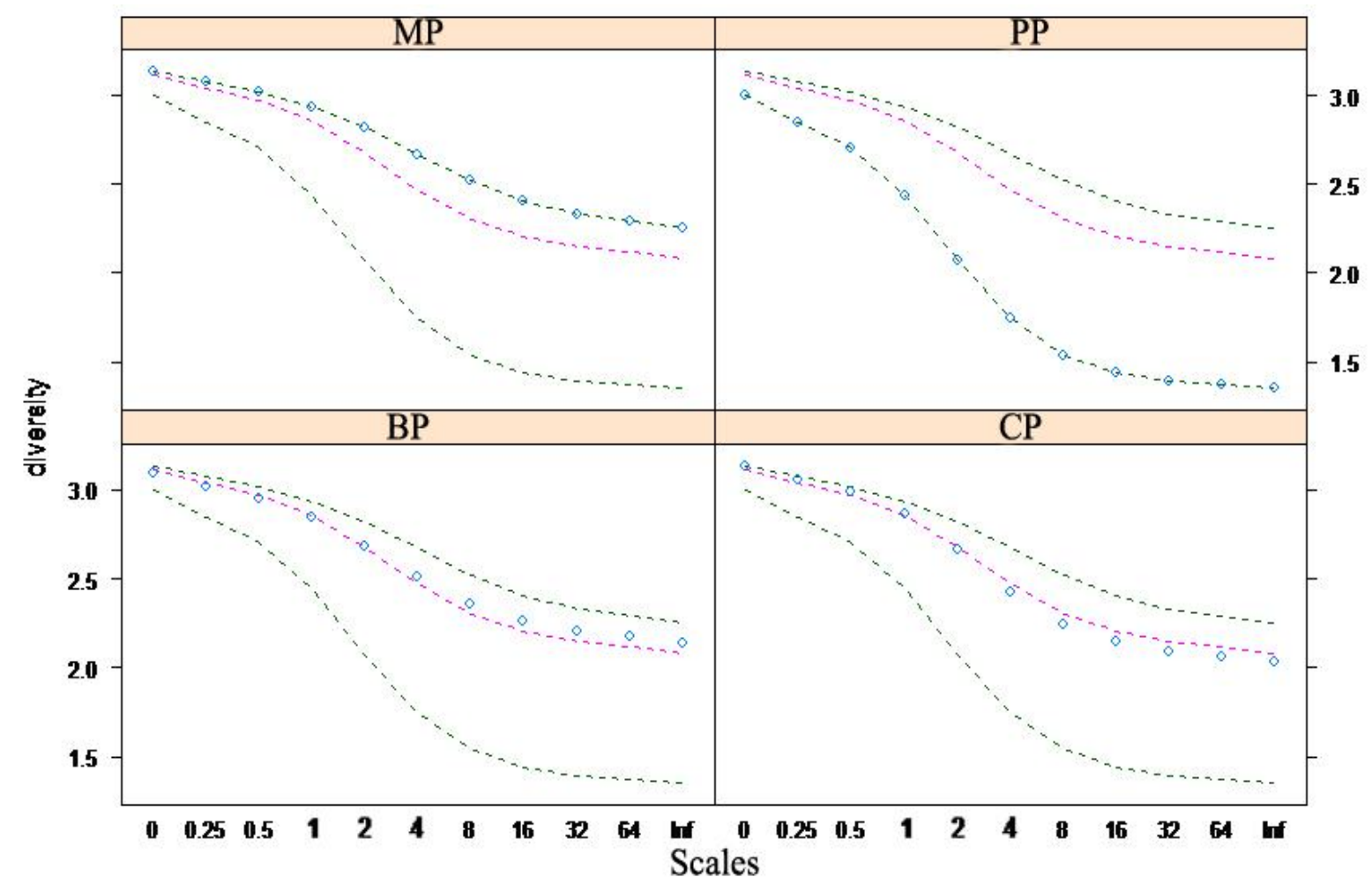

Fig. 1. Renyi diversity index of four plots $(B P, C P, M P$ and $P P)($ Shannon=1, Invsim=2 and Evenness $=4$ in scales axis).

\section{Indicator value analysis of different genera}

The indicator values (Dufrene and Legendre, 1997) of different genera were analyzed for season and experimental plots. Function (indval) within package (labdsv) were used in $\mathrm{R}$ for the analysis of individual indicator values of our genera (Table 3). Most of the genera were classified in MP (Table 2).

\section{Relative contribution of trophic groups by treatment plots}

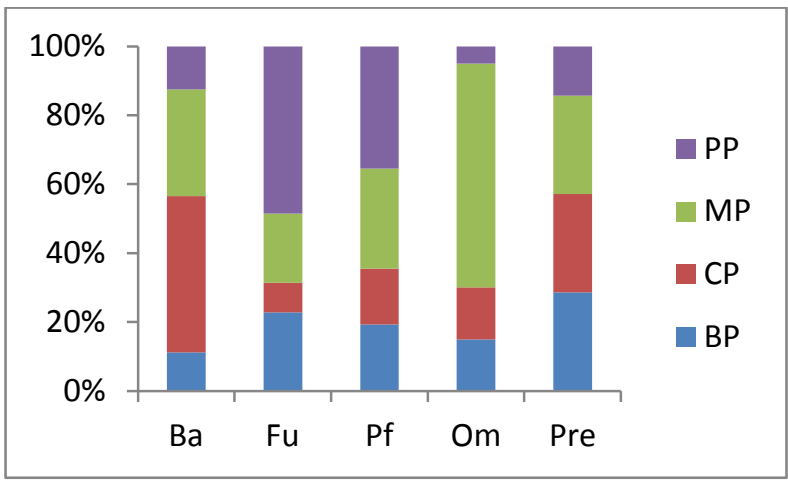

Fig.2. The relative (\%) contribution of trophic groups to nematode communities according to treatment plots.
Higher contribution of Bacterivores in control plot (CP) followed in cattle urine applied plot (MP), highest contribution of fungivores in pesticides applied plots. Similarly, higher contribution of Omnivorous in urine mixture plot and relatively higher contribution of predatory nematodes in botanicals applied plots. Figure 2 reflects the above mentioned results.

\section{Effect of treatment plots with functional guilds}

One-way ANOVA was performed for functional guilds of nematodes to analyze the significant effect with experimental plots and seasons (Table 3). $\mathrm{Ba} 1, \mathrm{Ba} 2$ and $\mathrm{Fu} 2$ were significantly affected only with experimental plots. Mean abundance of functional guilds of nematodes were significantly higher in Urine mixture treated plot (MP) and followed by control and botanical pesticide applied plots. The abundance of functional guilds in pesticides applied plots (PP) was significantly decreased. Similarly, Omnivorous group (Om4) was affected significantly with both factors i.e. Seasons and experimental plots as depicted in figure 1 . There was no significant variation with mean abundance of other function guilds across all treatment plots and seasonality. 
Table 2: Indicator value of genera by plots_ $(\mathrm{Bp}=$ plot treated with plant pesticides, $\mathrm{CP}=\mathrm{Control}$ plot, $\mathrm{MP}=$ Urine mixture treated plot and $\mathbf{P P}=$ pesticide treated plot).

\begin{tabular}{|c|c|c|c|c|c|}
\hline \multirow[t]{2}{*}{ Genera } & \multicolumn{4}{|c|}{ Indicator value with plots } & \multirow[t]{2}{*}{ Treatment plot with significance level } \\
\hline & BP & $\mathrm{CP}$ & MP & $\mathrm{PP}$ & \\
\hline Achromadora & 0.19 & 0.01 & 0.06 & 0.00 & $\mathrm{BP} *$ \\
\hline Acrobeles & 0.08 & 0.03 & 0.39 & 0.00 & $\mathrm{MP} * * *$ \\
\hline Acrobeloides & 0.04 & 0.02 & 0.15 & 0.01 & MP \\
\hline Aphelenchoides & 0.04 & 0.06 & 0.00 & 0.23 & $\mathrm{CP} *$ \\
\hline Aphelenchus & 0.03 & 0.00 & 0.01 & 0.15 & $\mathrm{CP}$ \\
\hline Cephalobus & 0.21 & 0.10 & 0.29 & 0.13 & MP \\
\hline Criconemella & 0.06 & 0.00 & 0.09 & 0.07 & MP \\
\hline Diploscapter & 0.03 & 0.01 & 0.22 & 0.01 & $\mathrm{MP}^{* *}$ \\
\hline Ditylenchus & 0.03 & 0.02 & 0.01 & 0.41 & $\mathrm{CP} * * *$ \\
\hline Dorylaimus & 0.01 & 0.11 & 0.15 & 0.11 & MP \\
\hline Eucephalobus & 0.07 & 0.08 & 0.13 & 0.07 & MP \\
\hline Helicotylenchus & 0.18 & 0.24 & 0.09 & 0.16 & $\mathrm{CP}$ \\
\hline Heterocephalobus & 0.01 & 0.02 & 0.07 & 0.03 & MP \\
\hline Longidorous & 0.02 & 0.02 & 0.16 & 0.01 & MP \\
\hline Malenchus & 0.00 & 0.04 & 0.09 & 0.01 & MP \\
\hline Mesorhabiditis & 0.00 & 0.05 & 0.23 & 0.00 & $\mathrm{MP}^{* *}$ \\
\hline Mononchus & 0.00 & 0.03 & 0.22 & 0.00 & MP** \\
\hline Panagrolaimus & 0.07 & 0.02 & 0.10 & 0.02 & MP \\
\hline Pratylenchus & 0.01 & 0.08 & 0.13 & 0.00 & MP \\
\hline prismatolaimus. & 0.00 & 0.02 & 0.13 & 0.01 & MP \\
\hline Rhabditis & 0.08 & 0.19 & 0.30 & 0.00 & MP* \\
\hline Trichodorous & 0.05 & 0.09 & 0.16 & 0.03 & MP \\
\hline Zeldia & 0.03 & 0.03 & 0.27 & 0.06 & MP* \\
\hline
\end{tabular}

$* * * \mathrm{p}<0.0001, * * \mathrm{p}<0.01, * \mathrm{p}<0.05$ 
Table 3: One way ANOVAs of function guilds with treated plots and season. (W-Winter and SSummer)

\begin{tabular}{|c|c|c|c|c|c|c|c|}
\hline & & plot & df & Mean & Stdv & F-value & $\mathbf{p}$ \\
\hline \multirow{6}{*}{ Ba1 } & \multirow{4}{*}{ Plots } & $\mathrm{BP}$ & \multirow{4}{*}{3} & 2.44 & 3.17 & \multirow{4}{*}{4.663} & \multirow{4}{*}{0.01} \\
\hline & & $\mathrm{CP}$ & & 4.22 & 9.77 & & \\
\hline & & $\mathrm{MP}$ & & 8.67 & 7.96 & & \\
\hline & & PP & & 0.94 & 1.98 & & \\
\hline & \multirow{2}{*}{ Seasons } & $S$ & \multirow{2}{*}{1} & 4.5 & 8.36 & \multirow{2}{*}{0.26} & \multirow{2}{*}{ ns } \\
\hline & & W & & 3.64 & 5.55 & & \\
\hline \multirow{8}{*}{$\mathrm{Ba} 2$} & \multirow{4}{*}{ Plots } & $\mathrm{BP}$ & \multirow{4}{*}{3} & 3.83 & 3.63 & \multirow{4}{*}{8.19} & \multirow{4}{*}{0.001} \\
\hline & & $\mathrm{CP}$ & & 2.44 & 3.33 & & \\
\hline & & $\mathrm{MP}$ & & 8.5 & 6.16 & & \\
\hline & & $\mathrm{PP}$ & & 2.5 & 3.11 & & \\
\hline & \multirow{2}{*}{ Seasons } & $S$ & \multirow{2}{*}{1} & 5.5 & 5.41 & \multirow{4}{*}{4.49} & \multirow{4}{*}{ ns } \\
\hline & & $\mathrm{W}$ & & 3.13 & 3.92 & & \\
\hline & \multirow{2}{*}{ Seasons } & S & \multirow{2}{*}{1} & 1.94 & 4.19 & & \\
\hline & & $\mathrm{W}$ & & 0.75 & 2.01 & & \\
\hline \multirow{6}{*}{$\mathrm{Fu} 2$} & \multirow{4}{*}{ Plots } & $\mathrm{BP}$ & \multirow{4}{*}{3} & 1.94 & 2.48 & \multirow{4}{*}{5.63} & \multirow{4}{*}{$0.00 * * *$} \\
\hline & & $\mathrm{CP}$ & & 0.83 & 1.04 & & \\
\hline & & $\mathrm{MP}$ & & 0.83 & 1.76 & & \\
\hline & & $\mathrm{PP}$ & & 4.67 & 5.62 & & \\
\hline & \multirow{2}{*}{ Seasons } & $S$ & \multirow{2}{*}{1} & 2.78 & 3.73 & \multirow{2}{*}{2.97} & \multirow{2}{*}{ ns } \\
\hline & & W & & 1.36 & 3.23 & & \\
\hline \multirow{9}{*}{ Om4 } & & $\mathrm{BP}$ & & 0.39 & 0.92 & & \\
\hline & & $\mathrm{CP}$ & & 0.78 & 0.88 & & \\
\hline & Plots & $\mathrm{MP}$ & 3 & 2.61 & 4.35 & 3.74 & 0.015 \\
\hline & & $\mathrm{PP}$ & & 0.5 & 0.51 & & \\
\hline & & S & & 1.64 & 3.26 & & \\
\hline & Seasons & $\mathrm{W}$ & & 0.50 & 0.70 & & \\
\hline & & $\mathrm{W}$ & 1 & 1.75 & 1.36 & 4.20 & 0.044 \\
\hline & & $\mathrm{W}$ & & 0.50 & 0.74 & & \\
\hline & & W & & 0.17 & 0.45 & & \\
\hline
\end{tabular}



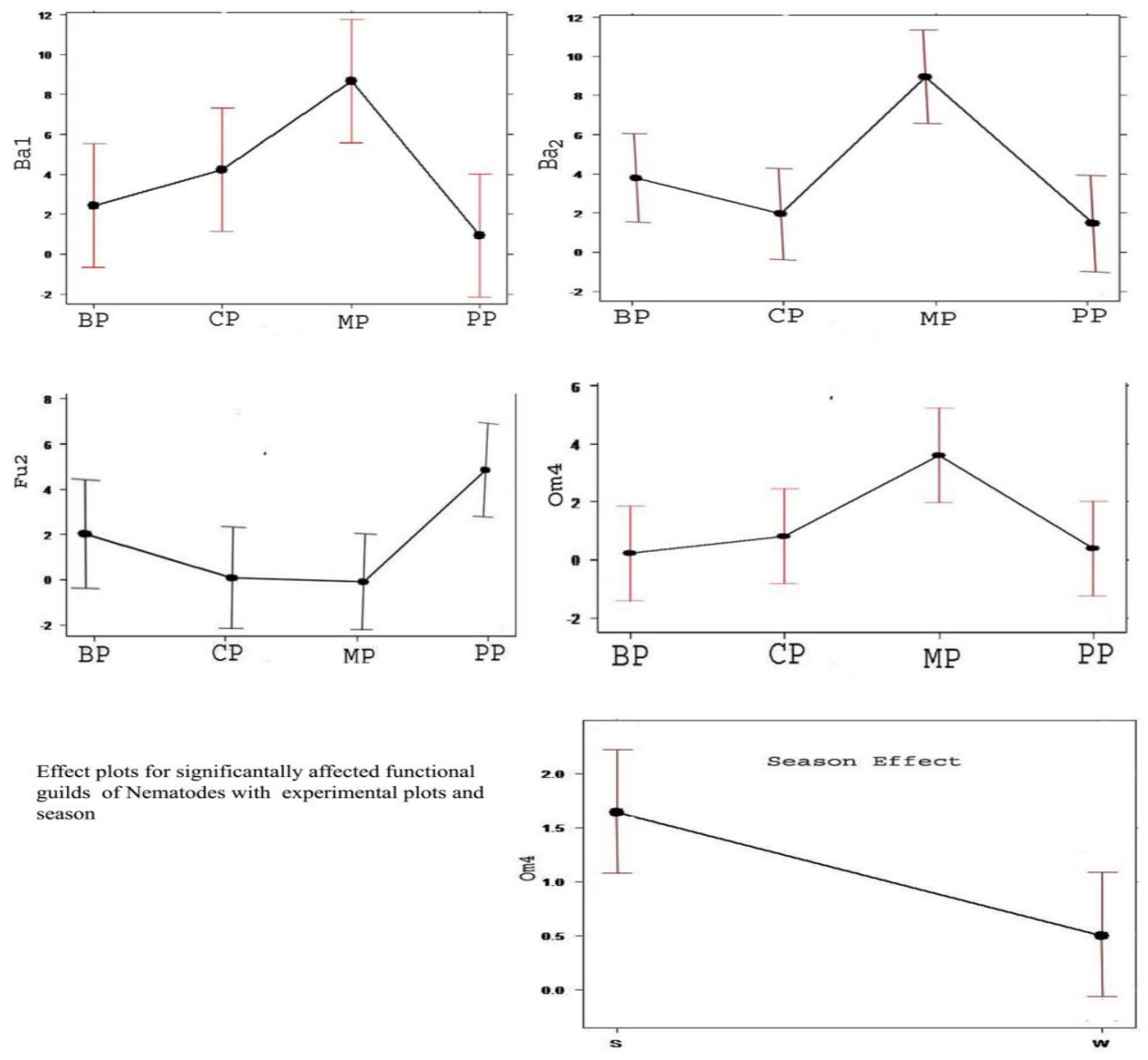

Fig. 3. Significantly affected functional guilds with treatment plots $(B P, C P, M P$, and $P P)$ and seasons $(S, W)$.

\section{Discriminate analysis:}

The abundance of nematode genera were separated in ordinate therefore to determined the discrimination of treated plot samples based on generic abundance. All treated plots were well separated (Fig. 3) in ordination. In this analysis the pesticides treated plots were followed by fungivores groups (Fu2) in first axis. The control plot (CP) was mostly followed by Bacterivores (Ba1) and Plant feeders (pf2). Similarly, other function guilds such as Omnivorous (om4), predator (pr5) and Bacterivores (ba2 and ba3) were followed to the urine mixture applied plots (MP).
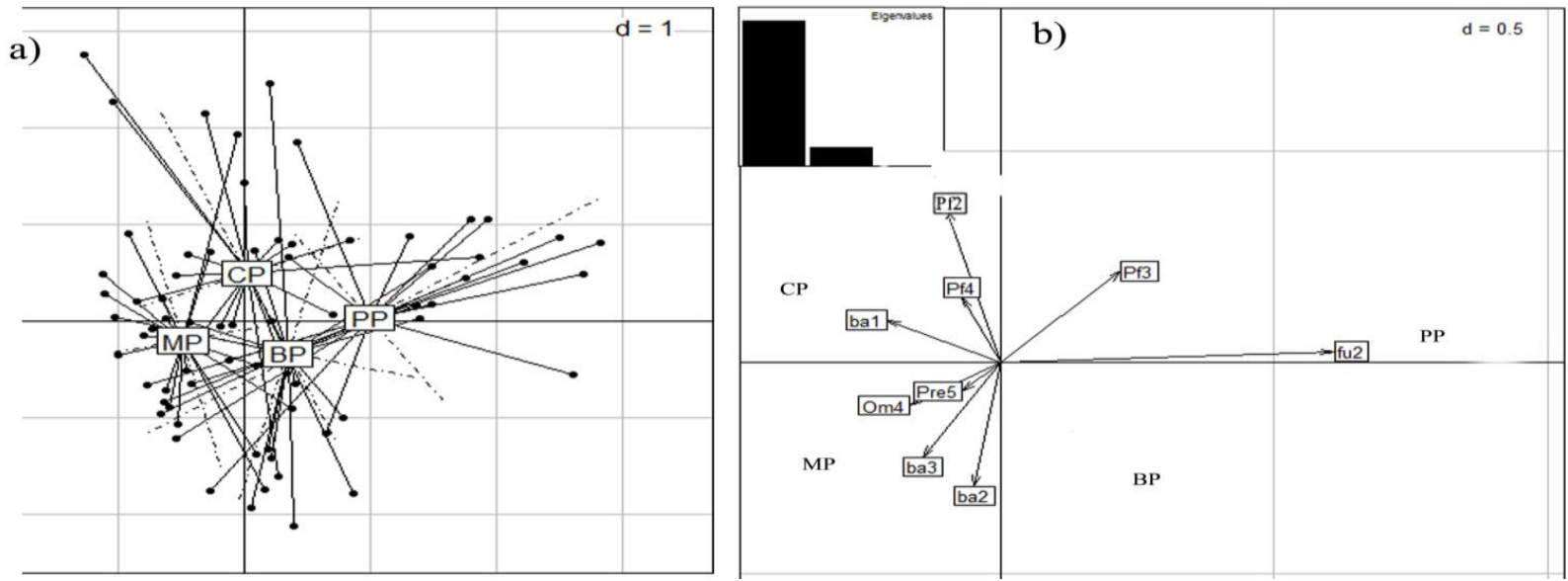

Fig. 4. Between analysis (two axes plane) for the ordination of nematode communities based on abundances per genus and sample. a) Genera b) Functional guilds composition and plots. 


\section{Plot*season effect plot}

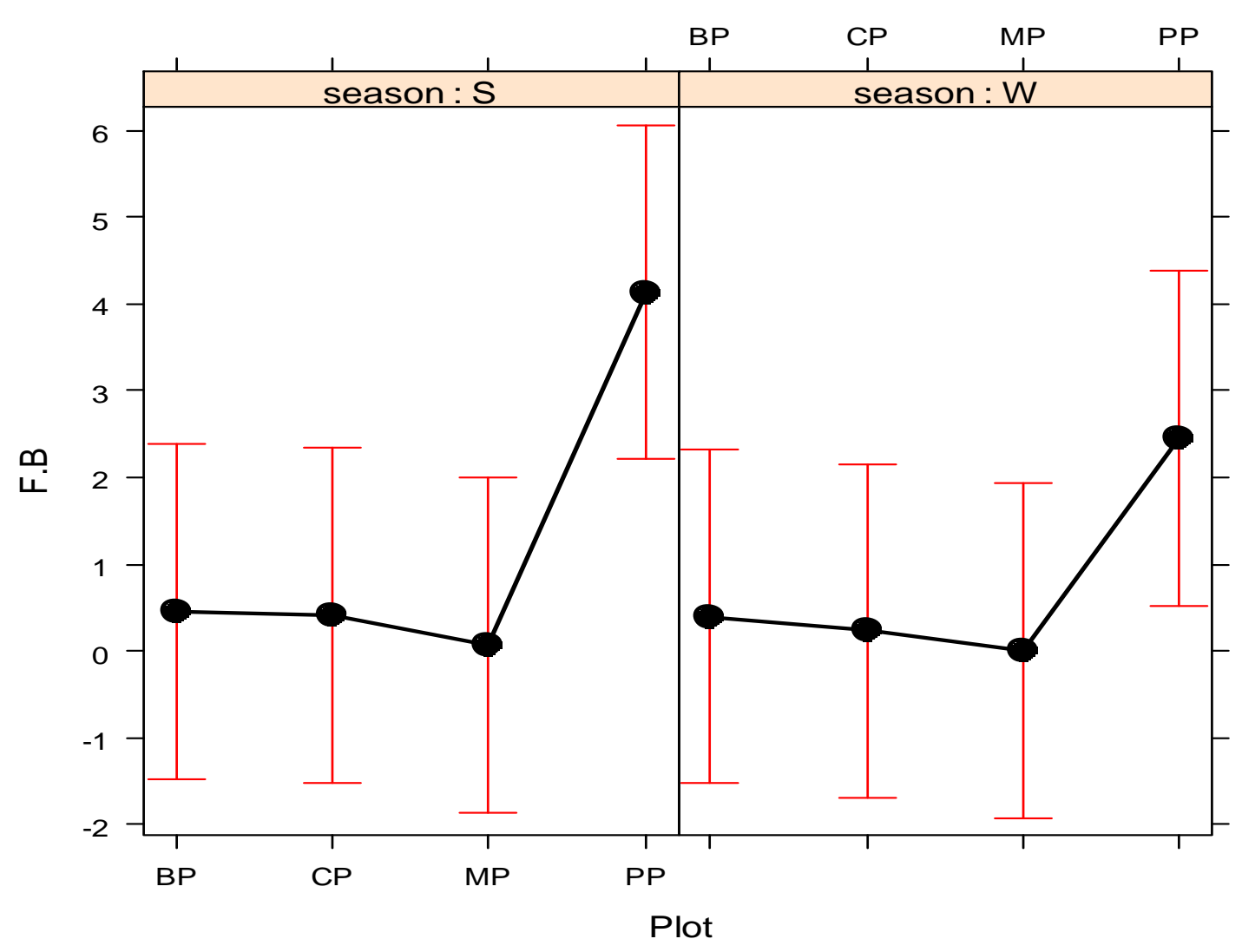

Fig. 5. The effect plot for the ratio of fungal to bacterial feeding nematodes (F/B) in treatment plots, seasons.

\section{F/B ratio in treated plots and season:}

The abundance ratio of fungal to bacterial $(\mathrm{F} / \mathrm{B})$ feeder nematodes was determined performing two way ANOVAs with for treatment plots and seasons (Fig. 4 and 5). The mean of treated plots were significantly affected with this ratio, whereas this ratio had no significant effect with seasonality as well as the interaction between seasonality and plots (Table 4).

Table 4: Summary result of two- way ANOVAs performed for $F$ : $B$ ratio with plots and seasons

\begin{tabular}{|l|l|l|l|l|}
\hline Factors & Sum sq & Df & F-value & $\boldsymbol{p}$-vale \\
\hline Plot & 125.12 & 3 & $\mathbf{5 . 1 7 2}$ & $\mathbf{0 . 0 0 3}$ \\
\hline season & 4.46 & 1 & 0.531 & $n s$ \\
\hline Plot: season & 8.57 & 3 & 0.340 & $n s$ \\
\hline
\end{tabular}

\section{DISCUSSION}

The treatment system was significantly affected rather than seasonal variation for abundance and diversity of nemato-fauna in experimental plots. The proportions of the different feeding groups in the soil nematode community vary between treatment systems and seasons, and they are influenced by a variety of factors, physical and biological characteristics of the soil that influence the abundance of nematodes (Freckman and Ettema, 1993; Ferris et al., 2001). Higher value of Shannon diversity index $(\mathrm{H})$ and evenness obtained in Urine mixture treated plots than other probably attributed resources variability (Bongers and Ferris, 1999) due to application of organic byproducts. Meanwhile, significantly decreased diversity indices in pesticides applied plots linked to the sensitivity of nematode genera with application of chemical compounds. The result is comparable with Fiscus and Neher (2002). Further, most of the genera can be classified as indicator species in urine mixture plots (MP) and only fungivores were found to be important indicators for pesticides applying plot (PP). The abundance samples of function guilds of nematodes were well separated in our discriminate ordination indicating the effect of 
abundance of nematodes in different treatment system within experimental plots. The response of functional guilds varied differently with treatment system (Briar et al., 2007; Nahar et al., 2006 ) also explained the Urine mixture added plots posses greater bacterial feeding nematodes than managed with conventional practices (Briar et al., 2007). Probably it is associated with the more nitrogen availability in urine mixture plot. The response variation in our system by functional guilds was probably attributed to change in microhabitat characteristics as well as the effect of resources variation especially in urine mixture plots. Eisenhauer et al. (2012) indicated the elevated availability of nitrogen significantly increased the density of opportunistic bacterial community (all bacterial guilds). Increased nematodes parameters in MP compared to other plots especially found decreased in pesticides plot indicating chemical response by nematodes community (Bongers and Ferris, 1999; Bardgett and Wardle, 2010; Kapagianni et al., 2010). Plots resource dynamics and microphysical parameters with seasons attribute the change in taxonomic and functional composition of nematodes playing the leading role in shaping nematode communities composition (Ekschmitt et al., 2003; Bakonyi et al., 2007). In this study, the plots found significantly affected with $\mathrm{F} / \mathrm{B}$ attributing the fungal dominated decomposition pathway especially in pesticide treated plots. The pesticide applying plot (PP) was significantly higher than other treatment plots indicates also a relatively higher contribution of fungal feeding nematodes. The decomposition pathway varied with treatment process that is fungal dominated decomposition process in our pesticide applying plot, whereas other plots were dominated to bacterial decomposition pathway.

In conclusion, it is clear, that organic byproducts application for pest management can increase soil nematodes diversity and abundance probably through the stimulation of microorganisms and other favorable biotic and abiotic factors in food webs. Effect of pest management system in Tomato farming had influence on changing abundance, diversity and communities of nematodes. Chemical pesticides used plots showed significant decreased in the abundance of genera, functional guilds and feeding group. Whereas, urine mixture used plot had relatively higher diversity of nematode genera and community probably attributed the resources inputs comparison to other treatment types. The decomposition pathway varied with treatment process that was fungal dominated decomposition in our pesticide applied plot but other plots were dominated by bacterial decomposition. It may be associated with characteristics in soil due to change in management inputs. Further understanding is needed regarding the soil biota and nematode diversity and community composition for the stability of soil ecosystem while performing the insect pest management practices at least for application of cattle urine mixture and botanicals than other chemical substances in Nepalese tomato farms.

\section{ACKNOWLEDGEMENT}

One of us D. K. is grateful to Small Research Grant-2016 (SRD), University Grant Commission (UGC), Nepal for partial support. We thank to Central Department of Zoology, Tribhuvan University for providing necessary laboratory facility. Organic farming Centre Tokha, Katmandu is acknowledged for providing necessary land to setup the experiment.

\section{REFERENCES}

Abawi, G. S. and Widmer, T. L. (2000). Impact of soil health management practices on soilborne pathogens, nematodes and root diseases of vegetable crops. Applied soil ecology, 15 (1): 37-47.

Andersson, P. (1988). Ordination and classification of operational geographic units in Southwest Sweden. Vegetatio, 74: 95-106.

Bhusal, D. R.; Tsiafouli, M. A. and Sgardelis, S. P. (2015). Temperature-based bioclimatic parameters can predict nematode metabolic footprints. Oecologia, 179 (1): 187-199.

Bhusal, D. R.; Tsiafouli, M. A. and Sgardelis, S. P. (2015). Temperature-based bioclimatic parameters can predict nematode metabolic footprints. Oecologia, 179 (1): 187-199.

Bongers, T. (1990). The maturity index: an ecological measure of environmental disturbance based on nematode species composition. Oecologia, 83(1), 14-19.

Bongers, T. and Ferris, H. (1999). Nematode community structure as a bioindicator in environmental monitoring. Trends in Ecology \& Evolution, 14: 224-228.

Bongers, T. and Bongers, M. (1998). Functional diversity of nematodes. Applied Soil Ecology, 10 (3): 239-251. 
Bongers, T. and Bongers, M. (1998). Functional diversity of nematodes. Applied Soil Ecology, 10: 239-251.

Bongers, T. and Howard F. (1999). Nematode community structure as a bioindicator in environmental monitoring. Trends in Ecology \& Evolution, 14 (6): 224-228.

Boström, S. and Sohlenius, B. (1986). Short-term dynamics of nematode communities in arable soil Influence of a perennial and an annual cropping system. Pedobiologia, 29 (5): 345357.

Bremner, J. M. (1996). Nitrogen-total. In: DL Sparks. Methods of soil analysis. Part 3. Chemical Methods. Madison, MI: ASA and SSSA. pp. 1085-1086.

Briar, S. S.; Barker, C.; Tenuta, M. and Entz, M. H. (2012). Soil nematode responses to crop management and conversion to native grasses. Journal of nematology, 44 (3): 245.

de Goede, R. G. and Bongers, T. (1994). Nematode community structure in relation to soil and vegetation characteristics. Applied Soil Ecology, 1 (1): 29-44.

Eisenhauer, N.; Beßler, H.; Engels, C.; Gleixner, G.; Habekost, M.; Milcu, A. et al. (2010). Plant diversity effects on soil microorganisms support the singular hypothesis. Ecology, 91 (2): 485-496.

Ferris, H. (2010). Form and function: metabolic footprints of nematodes in the soil food web. European Journal of Soil Biology, 46 (2): 97-104.

Ferris, H. and Bongers, T. (2006). Nematode indicators of organic enrichment. Journal of nematology, 38 (1): 3.

Ferris, H.; Lau, S. and Venette, R. (1994). Population energetics of bacterial-feeding nematodes: respiration and metabolic rates based on carbon dioxide production. Soil Biology and Biochemistry.

Fiscus, D. A. and Neher, D. A. (2002). Distinguishing sensitivity of free-living soil nematode genera to physical and chemical disturbances. Ecological Applications, 12 (2): 565-575.

Gebremikael, Mesfin T. et al. (2016). Nematodes enhance plant growth and nutrient uptake under $\mathrm{C}$ and $\mathrm{N}$-rich conditions. Scientific reports, $\mathbf{6}$.
Goralczyk, K. (1998). Nematodes in a coastal dune succession: Indicators of soil properties? Applied Soil Ecology, 9 (1): 465-469.

Jones Jr, J. B. (1991). Kjeldahl method for nitrogen determination. Kjeldahl method for nitrogen determination.

Jouquet, P.; Dauber, J.; Lagerlöf, J.; Lavelle, P. and Lepage, M. (2006). Soil invertebrates as ecosystem engineers: intended and accidental effects on soil and feedback loops. Applied Soil Ecology, 32 (2): 153-164.

Kapagianni, P. D.; Boutsis, G.; Argyropoulou, M. D.; Papatheodorou, E. M. and Stamou, G. P. (2010). The network of interactions among soil quality variables and nematodes: shortterm responses to disturbances induced by chemical and organic disinfection. Applied soil ecology, 44 (1): 67-74.

McSorley, R. and Frederick, J. J. (1999). Nematode population fluctuations during decomposition of specific organic amendments. Journal of nematology, 31 (1): 37.

McSorley, R. and Frederick, J. J. (1999). Nematode population fluctuations during decomposition of specific organic amendments. Journal of nematology, 31 (1): 37.

Mitschunas, N.; Wagner, M. and Filser, J. (2006). Evidence for a positive influence of fungivorous soil invertebrates on the seed bank persistence of grassland species. Journal of Ecology, 94 (4): 791-800.

Mulder, C.; Moit, A.; Bonkowski, M.; Peter, C.; de Ruiter, P. C.; Mancinelli, G. et al. (2011). A Belowground Perspective on Dutch Agroecosystems: How Soil Organisms Interact to Support Ecosystem Services. $A d v$ Ecol Res, 44: 277-357.

Neher, D. A. and Olson, R. K. (1999). Nematode communities in soils of four farm cropping management systems. Pedobiologia, 43 (5): 430-438.

R Development Core Team (2017). R: A Language and Environment for Statistical Computing. $\mathrm{R}$ Foundation for Statistical Computing, Vienna. http://www.R-project.org .

Shepherd, A. M. (1970). Preparation of nematodes for electron microscopy. In: Southey J. F. (ed) Laboratory methods for work with plant and soil nematodes, HMSO, London, UK. pp. 88-95. 
Sohlenius, B. and Wasilewska, L. (1984). Influence of irrigation and fertilization on the nematode community in a Swedish pine forest soil. Journal of Applied Ecology, 21: 327342.

Tewary, D. K.; Bhardwaj, A. and Shanker, A. (2005). Pesticidal activities in five medicinal plants collected from mid hills of western Himalayas. Industrial crops and Products, 22 (3): 241-247.

Tsiafouli, M. A.; Bhusal, D. R. and Sgardelis, S. P. (2017). Nematode community indices for microhabitat type and large scale landscape properties. Ecological Indicators, 73: $472-$ 479.

Tsiafouli, M. A.; Kallimanis, A. S.; Katana, E.; Stamou, G. P. and Sgardelis, S. P. (2005). Responses of soil microarthropods to experimental short-term manipulations of soil moisture. Applied Soil Ecology, 29 (1): 17-26.

Tsiafouli, M. A.; Thébault, E.; Sgardelis, S. P.; Ruiter, P. C.; Putten, W. H.; Birkhofer, K. et al. (2015). Intensive agriculture reduces soil biodiversity across Europe. Global change biology, 21 (2): 973-985.

Van Der Heijden, M. G.; Bardgett, R. D. and Van Straalen, N. M. (2008). The unseen majority: soil microbes as drivers of plant diversity and productivity in terrestrial ecosystems. Ecology letters, 11 (3): 296-310.
Walkley, A. and Black, I. A. (1934). An examination of the Degtjareff method for determining soil organic matter, and a proposed modification of the chromic acid titration method. Soil science, 37 (1): 29-38.

Wall, D. H. (2012). Soil Ecology and Ecosystem Services (eds Wall DH, Bardgett RD, BehanPelletier V, Herrick JE, Jones H, Ritz K,et al. Oxford: Oxford University Press. pp. 424.

Wolters, V. (2000). Invertebrate control of soil organic matter stability. Biology and fertility of Soils, 31 (1): 1-19.

Yang, Y., et al. (2016). Differential responses of soil nematode community to pig urine mixture application levels in Ferric Acrisols. Scientific reports, 6.

Yeates, G. W. and Bongers, T. (1999). Nematode diversity in agroecosystems. Agriculture, Ecosystems \& Environment, 74 (1): 113-135.

Yeates, G. W.; Bongers, T. D.; De Goede, R. G. M.; Freckman, D. W. and Georgieva, S. S. (1993). Feeding habits in soil nematode families and genera - an outline for soil ecologists. Journal of nematology, 25 (3): 315.

Yeates, G. W. and Bongers, T. (1999). Nematode diversity in agroecosystems. Agriculture, Ecosystems and Environment, 74: 113-135.

Zhao, J. and Neher, D. A. (2013). Soil nematode genera that predict specific types of disturbance. Applied Soil Ecology, 64: 135-141. 